\title{
Lektorálástudomány - fordításban
}

\author{
Robin Edina \\ E-mail: robin.edina@btk.elte.hu
}

\begin{abstract}
Kivonat: A tudományfordítás, vagyis tudományos szakmunkák, szakkönyvek és szakcikkek fordítása egyelöre nem elterjedt gyakorlat a magyar nyelvterületen, elsősorban önfordítással szoktunk találkozni (Pusztai-Varga 2018, Károly 2020). Különösen igaz ez a fordítástudomány esetében, ahol a tanulmányokat író fordításkutatók maguk is gyakorló fordítók vagy tolmácsok, így nincs szükségük rá, hogy a munkájuk mások tolmácsolásában jelenjen meg egy adott célnyelven. A jelen beszámolóban szereplö Lektorálástudomány - forditásban (Robin és Zachar 2020) címü tanulmánykötet éppen ezért fontos mérföldkőnek tekinthetö, hiszen egy fordítástudományi szakcikkeket magyar fordításban közlő könyvsorozat második, tematikus köteteként jelent meg. Először is szót ejtek a tanulmánykötet keletkezésének hátteréről és a téma relevanciájáról, majd bemutatom a szerzőket és a tanulmányokat, valamint a fordítástudományi szövegek fordítása során jelentkező kihívásokat. Szó esik továbbá a szerző, a fordító és a lektor szerepében eljáró témavezető együttmüködéséről, amelyhez egy szakdolgozat alapját képező fordítástudományi szaktanulmány ideális lehetőséget nyújt. Végezetül összefoglalom, milyen szempontból tekinthető sikernek a tudományfordításokat közlő tanulmánykötet megszületése.
\end{abstract}

Kulcsszavak: tudományfordítás, fordítástudomány, lektorálástudomány, terminológia, lektorálási spirál

\section{Bevezetés}

Az Eötvös Loránd Tudományegyetem Fordító- és Tolmácsképző Tanszékén tanulmányaikat folytató másodéves hallgatók fordításait tartalmazó első tanulmánykötet, a Fordítástudomány - fordításban (Robin és Varga 2018), amelynek születéséről részletes beszámoló is szól (Robin 2018), máris hasznos forrásnak bizonyult nem csupán a mesterszakos szakfordító hallgatók, hanem a vizsgálódásaikat foly-

Hivatkozás: Robin E. 2020. Lektorálástudomány - fordításban. Fordító- és tolmácsképzés Németországban. Forditástudomány 22. évf. 2. szám. 93-106.

DOI: https://doi.org/10.35924/fordtud.22.2.5. 
tató doktoranduszok és fordításkutatók számára is. Hivatkozható tudományos szakcikkek fordításait tartalmazza magyar nyelven, megkönnyítve a magyarul íródó fordítástudományi szakmunkák megalkotását, elsősorban a megfelelő terminushasználat szempontjából, hiszen a fordítások elkészítését minden tanulmány esetében alapos és szakszerü terminológiai munka előzte meg. A terminológiai előkészítés során összegyüjtött, definícióval, forrásokkal és kereszthivatkozásokkal ellátott terminusok pedig egy igencsak időszerü (Klaudy 2014, 2020), elökészületben lévő, négynyelvü fordítástudományi szótár alapjául is szolgálnak, amelynek munkálatai jelenleg is folynak.

Az első kötet sikere után hamarosan megszületett a döntés, hogy a hallgatói projekt egy könyvsorozat keretében folytatódjon tovább. Habár az előző kötet a fordítástudomány számos területéről tartalmaz tanulmányokat a fordításpedagógiától kezdve az audiovizuális fordításon át a tolmácsolásig, általános betekintést nyújtva a fordítástudomány témaköreibe, a sorozatot egy tematikus kötet összeállításával kívántuk folytatni, amely fordítások lektorálásáról szóló tanulmányokat foglal magában. A témaválasztás több okból is relevánsnak és aktuálisnak tünt. Egyrészt a lektorálás kutatása az utóbbi időben egyre nagyobb érdeklődésnek örvend a hazai és nemzetközi fordításkutatók körében (Robert 2018), ami elsősorban a fordítások minőségére vonatkozó nemzetközi szabványok miatt megnövekedett lektorálási szükségletnek köszönhető. Másrészt éppen az említett okból egyre nagyobb igény mutatkozik a lektorképzésre is, ezért az ELTE Fordító- és Tolmácsképző Tanszékén Magyarországon elsőként indítottunk el egyetemi képzést a lektorálás iránt érdeklődők számára. Mivel új kutatási irányzatról van szó, egyelőre kevés magyar nyelvü szakirodalom áll a kutatók, hallgatók és gyakorló lektorok rendelkezésére, és a lektorálástudományi tanulmánykötettel ezen a hiányon szerettünk volna enyhíteni.

\section{Szerzők és tanulmányok}

A projektben részt vevő hallgatók - ahogyan az első tanulmánykötet esetében is történt - a szakdolgozatokra vonatkozó követelmények szerint választották ki a fordítandó forrásnyelvi szövegeket: öt évnél nem régebbi, szakemberek által szakembereknek írt tudományos cikkek közül keresgélhettek a lektorálás témakörén belül, angol, német és francia forrásnyelven. A kiválasztott tanulmányok jól illusztrálják, milyen területek tartoznak a lektorálás témakörébe: szerkesztés a fordításon belül, önlektorálás és más munkájának lektorálása, gépi fordítás utószerkesztése, sőt a fordítástámogató eszköz használata során végzett ellenőrző, szerkesztési tevékenység is. A fordított cikkek a nemzetközi szakirodalom elismert irodalomtudományi, nyelvtudományi és kifejezetten fordítástudományi folyóirataiból származnak (Target, Meta, Perspectives, Translation Studies, The Translator, trans kom, The Interpreter and Translator Trainer, JoSTrans, Paralleles, TTR). Az egyik 
fordítás a Target Online felületén is megjelent ${ }^{1}$. A kiválasztott cikkek számos esetben jelentősen hosszabbnak bizonyultak a szakdolgozathoz szükséges harmincezer leütésnél, de a hallgatók vállalták, hogy a magyar nyelvü publikációhoz lefordítják a szövegek fennmaradó részét is. A választott cikkek között szerepelnek elméleti eszmefuttatások, terminológiai fejtegetések, esettanulmányok, empirikus kutatás eredményeit feldolgozó cikkek és a lektorálástudomány jelenlegi állását összefoglaló tanulmányok.

A magyar kiadáshoz mindenképpen szükséges volt beszerezni a szerzők és az eredeti cikkeket megjelentető folyóiratok kiadójának hozzájárulását. Mivel a tanulmánykötetet az első kötethez hasonlóan kereskedelmi forgalomba nem kerülö, egyetemi kiadványként terveztük megjelentetni, nem ütközött jelentősebb akadályba a fordítási engedély megszerzése: a kiadók nagylelküen engedélyezték a cikkek fordításban történő reprodukcióját, azzal a feltétellel, hogy pontosan feltüntetjük hivatkozásban a cikk eredeti megjelenését. Csupán két cikk esetében volt szükséges jelképes díjat fizetnünk a szerzői jogokért.

Az előző kötet tapasztalatain felbátorodva vettük fel a kapcsolatot az eredeti szerzőkkel, akik megtiszteltetésnek vették, hogy a hallgatóink éppen az általuk írt tanulmányt választották, és örömmel adták beleegyezésüket a magyar nyelvü publikáláshoz. A szerzők között kanadai, olasz, belga, dán, német, amerikai, svájci és spanyol, fordítástudománnyal foglalkozó kutatót találunk - így a projekt valódi nemzetközi összefogás keretében jöhetett létre. Olyan jól ismert nevek és nemzetközi szaktekintélyek szerepelnek közöttük, mint Christina Schäffner, az Aston Egyetem professzora, és Alexander Künzli, a Genfi Egyetem professzora, aki a 2000-es évek eleje óta kutatja a lektorálás jellemzőit. A lektorálás kutatásával foglalkozó fordítástudományi cikkek hivatkozásaiban továbbá gyakran találkozhatunk Isabelle Robert, Louise Brunette és Giovanna Scocchera nevével is, akiknek az utóbbi években megjelent cikkei közül sikerült a Lektorálástudomány - fordításban tanulmányai közé is beválogatnunk néhányat. A szerzők is beleegyezésüket adták a tanulmányok magyar nyelvü újrapublikálásához, sőt a segítségüket is felajánlották a hallgatóknak, ha valahol elakadnak, mert nem értik pontosan a szöveget - erre néhány esetben sor is került.

\section{Együttmüködés}

A tanulmánykötet elkészítése - és a szakdolgozat alapjául szolgáló cikkfordítások megalkotása - tökéletes lehetőséget biztosított a harmonikus fordítási munkafolyamat megvalósításához: a szerkesztők megrendelőként, a témavezető oktatók

\footnotetext{
${ }^{1}$ Christopher D. Mellinger: A fordítások minőségének újragondolása: lektorálás a digitális korban. Fordította: Pete-Pikó Klára. https://benjamins.com/online/target/articles/target.16104.mel.hu
} 
nyelvi és szakmai lektorként, a hallgatók pedig fordítóként vettek részt a folyamatban. A szakdolgozat alapjául szolgáló fordításra a szakmában szokásos szoros határidő helyett több hónap állt rendelkezésre, így amennyiben a hallgatók hatékonyan kihasználták ezt az idöt, bőven volt lehetőségük a szövegek fordítása közben konzultálni a témavezetővel, illetve a szerkesztőkkel, és akár többször is átdolgozni a célnyelvi szöveget, hogy minél jobban megfeleljen a tudományos szakmunkák normáinak. Megvalósult tehát az a lektorálási spirál (Malaczkov 2020), amelynek során a célnyelvi szöveg a fordítási folyamat résztvevőinek együttmüködése eredményeként több körben megvalósuló ellenőrzés, módosítás és kölcsönös validálás (Robin 2019) után születik meg.

Ebben a folyamatban a fordító és a szövegét javító lektor együttes munkája erősen pedagógiai színezetü, hiszen a témavezető nem csupán a hibákra csap le, hanem munka közben ösztönzi is a hallgatót, tanácsokkal látja el, rávezeti a megoldásokra és a javításait mindig meg is indokolja, betöltve ezzel a lektor „mentor” szerepét is (Mohácsi-Gorove 2014, Robin 2019). A fordító-hallgató és a lektor-témavezető együttmüködését illusztrálja az alábbi rövid fordítói kommentár a translation proper kifejezés fordítása kapcsán:

A proper revision szórendben megfelelö(en végzett) lektorálás lett volna a választásom, ám így elbizonytalanodtam. Miért használt a szerző fordított szórendet? Hogyan tudom ezt megfelelően visszaadni a fordításomban? Talán a szöveg teljes lektorálását jelenti a kifejezés? Ebböl a gondolatból indulva átfogó lektorálás lett a választásom. Ezután egyeztettem témavezetőmmel, aki megerösített abban, hogy a fordított szórend a hangsúlyosabbá tételt hivatott szolgálni, viszont maga a lektorálás kap nyomatékot, így végül a tulajdonképpeni lektorálás mellett döntöttem. (Dobróka Anett)

Azonban a témavezető szerepe lektorként és mentorként nem korlátozódik pusztán a fordítástechnikai problémák megoldását célzó javaslatokra és nyelvhelyességi hibák javítására: terminológiai feladatokat ugyancsak ellát, vagyis terminológusként is közremüködik a fordítási folyamatban, segítve és felügyelve a fordító munkáját - ugyanakkor a lektor mint terminológus közremüködése a szakma gyakorlatától sem idegen. Ahogyan a későbbiekben arról még bővebben szó esik, az idegen nyelvü fordítástudományi terminusok magyar nyelven történő megfeleltetése nagy kihívások elé állítja a szakfordító hallgatót. Ilyenkor a szakirodalomban jártas, a szakterületet alaposan ismerö lektor-terminológus-témavezető közremüködése kulcsfontosságú a fordítási munkafolyamat során. A lefordított tanulmánynak ugyanis önállóan is meg kell állnia a helyét a magyar szakirodalomban, terminusainak illeszkedniük kell a szakterület kifejezéstárába. A szakfordító hallgatók egyik feladata ezért a fordítást előkészítő és támogató terminusjegyzék kidolgozása pontos definíciókkal, kontextussal, szakirodalmi hivatkozásokkal ellátva, amihez segítséget és útmutatást nyújtanak a témavezetök, ahogyan az alábbi fordítói kommentárból is kiderül: 
A straight translation/translator kifejezést sokáig kutattam. Az egyik gondot az okozta számomra, hogy még az angol nyelvü oldalakon sem találtam meg a pontos definícióját. Számos fordítói, illetve nyelvészeti portál böngészése után azonban világossá vált számomra, hogy a valódi, sokszor szóról szóra történő fordítás (olykor tükörfordítás) leírására használják. Fata (2012) írásában találkoztam a direkt fordítás definíciójával, a szöveg rámutatott a terminus jelentésére és a különböző kifejezésekre, amelyek mind ugyanazt a mủveletet - azaz a szó szerinti fordítást - jelölik. Ekkor direkt fordításként feleltettem meg a terminust, és utánanéztem az angol direct translation kifejezésnek is, amelyet sok helyen a straight translation szinonimájaként említenek. Ám témavezetőm rámutatott a direct translation egy másik jelentésére is, amely az anyanyelvre történő fordítást is jelöli (Ferreira et al. 2016) a szó szerinti fordítás mellett (Wakabayashi 2009). Így a kifejezés kétértelmüsége miatt mégis elvetettem ezt a megfelelöt. Ezután találtam meg az egyenes fordítás kifejezést, amelyet több megbízható forrás említ a szó szerinti fordítás megfelelőjeként. Visszatekintve jókora derültséget okoz ez számomra, hiszen amilyen egyszerü, annyira nehezen találtam rá a magyar megfelelöre, amely a straight translation terminus egyenes fordítása. (Varga Dóra)

Egy-egy terminus vagy szövegrészlet kapcsán az is előfordulhat, hogy a témavezető szakértelme mellett szükséges az eredeti szöveg szerzőjének segítsége is a kérdéses kifejezés pontos értelmezése, a szerző szándékának feltárása érdekében, nehogy félrefordítás szülessen; tudományfordításról lévén szó egy téves értelmezésnek hosszú távú negatív következményei is lehetnek. Az információs technikának és a globalizációnak köszönhetően ma már nem ütközik különösebb nehézségekbe a fordítandó szakcikkek szerzőivel való kapcsolatfelvétel. Ahogyan fentebb arról már szó esett, a tanulmányok eredeti szerzői felajánlották segítségüket a hallgatók számára, ha esetleg olyan nehézségekbe ütköznének, amelyet egyedül nem tudnak megoldani. Ilyen probléma merült fel a grammatical metaphor terminus megfeleltetése során is. A fordító, Miller Barbara felvette a kapcsolatot az eredeti tanulmány szerzőjével, Mario Bisiadával, aki készségesen segítségére sietett:

Első olvasatra nem volt számomra teljesen egyértelmü, mi lehet a szakszerü fordítás erre a terminusra, hiszen rögtön a szépirodalomban gyakran használatos metaforára asszociáltam, ilyesmiről a jelen tanulmányban azonban nyilvánvalóan egyáltalán nincs szó. Végül a cikk írójával, Mario Bisiadával való levelezés alapján hoztam meg fordítói döntésemet (személyes kommunikáció, 2019. január 24.):

„I just had to check this passage again and realised that this is indeed not a very good choice of terminology. The reason behind it is that I published this paper as part of a range of papers on editing and grammatical metaphor. Halliday (1985) defines grammatical metaphor as a change in grammatical 
category. So if we express an action, which would most naturally be expressed by a verb, as a noun, we speak metaphorically. I explain why I adopt this theory for my project in an article I published in Target [...], and my plan was to keep ,"metaphorisation” out of the other articles and just use ,verbalisation” or ,nominalisation”, but I see that the example you have found escaped me, and it indeed does not make sense as it is not used anywhere else in the paper. But as to the meaning of this particular phrase, it appears in the section on editors' reverbalisation, so I'm analysing the number of cases where editors turn nouns back into verbs. [...]"

A tanulmány írója elmagyarázta nekem, hogy a metaphorise terminus itt igésítést jelent. (Miller Barbara)

Az értelmezési problémát ilyen módon sikerült feloldani, és olyan megfeleltetés került a magyar nyelvü szövegbe, amellyel a szerző is egyetértett. Az idézett kommunikációból az is kiviláglik, hogy még a forrásnyelvi szöveg sincsen kőbe vésve, nem feltétlenül tökéletes, sőt előfordulhat, hogy a szerző a publikáció óta eltelt időben bizonyos kérdéses részletekkel kapcsolatban már módosítaná a véleményét - kifogásolható részek akár a mély feldolgozást igénylő fordítás során is felszínre kerülhetnek, ahogyan az idézett fordítói kommentárból is látszik. Éppen ezért tudományfordítás esetén mindenképpen tanácsos konzultálni az eredeti szöveg szerzőjével, amennyiben az értelmezés során kérdések merülnek fel.

A fentiek alapján is belátható, hogy a fordítási folyamat résztvevői közötti harmonikus együttmüködés kulcsfontosságú a fordított szövegek minősége szempontjából (Robin 2019). A fordítási folyamatban minden szereplőnek saját feladata és felelőssége van - az eredeti szöveg szerzőjétől kezdve a fordítón át a fordítást ellenörző és értékelő lektorig -, és a közöttük folyó hatékony kommunikáció jelentősen hozzájárul, hogy ez a folyamat sikerrel záruljon, a fordítás során felmerülő problémákat és kihívásokat pedig maradéktalanul meg tudják oldani.

\section{Kihívások a fordítás során}

A fordítástudományi szakcikkek magyar nyelvre történő átültetése során számos nehézségbe ütközhet a fordító. Kihívást jelenthet egyrészt maga a téma, hiszen bár a szakfordító hallgatók számára nem ismeretlen a fordítástudományi szakirodalom, tanulmányaik közben több elméleti tárgyat is teljesíteniük kellett, mégsem számítanak feltétlenül a tudomány müvelőinek, inkább gyakorlati szakemberek, így nem mélyültek el a tudományos gondolkodásban. Éppen ezért, bár nyelvileg nem okoz számukra gondot a forrásnyelvi szövegek feldolgozása, maga a téma és a mondanivaló megértése, ilyen módon pedig a fordítása során is problémákkal találkozhatnak. Ez a megállapítás érvényes lehet bármilyen tudományfordítás esetében, különösen amikor olyan szerteágazó és interdiszciplináris tudományról van 
szó, mint amilyen a fordítástudomány. Ezekben helyzetekben rendkívül fontos a témavezető, vagyis a témában jártas szakmai lektor hozzáértése és segítsége, hogy a fordítási folyamat eredményeként létrejövő szöveg tartalmilag kifogástalan legyen, valamint ahogyan fentebb láttuk, a szöveg értelmezésében maga az eredeti tanulmány szerzője is a fordító segítségére lehet.

Hasonló okból kihívást jelenthet - és a szakdolgozatban szereplő fordítói kommentárok alapján jelentett is - a forrásnyelvi szövegek tudományos nyelvhasználatának feldolgozása és a célnyelven való reprodukciója. Habár a szakfordító hallgatók fordításelméleti tanulmányai bizonyos mértékig biztosítottak számukra némi jártasságot a szakirodalomban, semmiképpen sem készítette fel őket a tudományos nyelvhasználatra, produkciós szinten nem ismerkedtek meg a fordítástudományi szakszövegek nyelvi és szakmai normáival, hagyományaival. Nyelvi szempontból nehézséget okozott a hosszú mondatok feldolgozása, valamint a kohézió és a koherencia megteremtése. További kihívás volt a tudományos szóhasználat, megfogalmazás és a megfelelő regiszter használata, továbbá a nyelvészeti, azon belül is a fordítástudományi szakmunkák formulaszerü nyelvi elemeinek helyes alkalmazása. Amennyiben a fordítónak és a lektornak sikerül mindezen jellemzőkre figyelmet fordítani, úgy gondoskodhatnak arról, hogy a szakterület normáinak megfelelö, nem pedig kvázi-helyes (Klaudy 1987) szöveg jöjjön létre.

A tudományos szövegeknek ugyancsak sajátos jellemzője a pontos hivatkozási rendszer alkalmazása, valamint egy megadott házi stílus követése. A kötetbe kiválogatott tanulmányok eredetileg különböző fordítástudományi folyóiratokban jelentek meg, amelyeknek mindegyike saját stíluslapot és hivatkozási rendszert használ. Mivel a fordításra válogatott cikkeket egyetlen közös kötetben akartuk megjelentetni, a fordítók feladata volt a szöveg teljes átszerkesztése is a Forditástudomány folyóirat sablonja szerint. Ez a tulajdonképpen technikai lépés korántsem volt egyértelmủ a fordítók számára, és különös precizitást követelt meg tőlük.

Fejtörést okozhat a szakfordítók számára az is, amikor hibákkal találkoznak a fordítandó forrásnyelvi szövegben, hiszen nem csupán fordításokban akadhatnak problémák, autentikus szövegekben is előfordulhatnak tényszerü hibák, következetlenségek, elütések, félreértést szülö tipográfiai hibák. Nem áltathatjuk magunkat a forrásnyelvi szöveg tökéletességével, egy fordítónak mindig éberen, kritikusan kell azt szemlélnie. Dilemmát okozhat azonban, mihez kezdjen a fordító a felfedezett hibával, ahogyan az alábbi fordítói kommentárban is olvashatjuk:

A témavezetőmmel folytatott konzultáció során felmerült, hogy az olvashatósági tesztek nehézségének bemutatásakor tipográfiai hiba, vagyis fölösleges szóköz lehet a konkrét számok felsorolásánál: „,...36, 45 ; 41, 99 ; 38, 27 ; 44, 06)". A tanulmány szerint ugyanis mind a négy szöveg 30 és 45 közötti pontszámot kapott, továbbá logikus és valószínüsíthetö, hogy mindegyik szöveghez egy érték tartozik. Ebböl következik, hogy a vesszővel elválasztott számok valójában összetartoznak, és csak tizedesvesszö van közöttük: ,[...] 36,45 ; 41,99 ; 38,27 ; 44,06”. Az elméletet azonban nem volt könnyü igazolnom, 
hiszen a módszert holland nyelvü szövegekre alkalmazzák, így a legtöbb ezzel kapcsolatosan elérhető forrás is holland nyelvü. Végül rábukkantam egy egyetemi tanulmányra, Van Laecke és Hadermann (2007) munkájára. Tanulmányukban bemutatják a Douma-Flesch módszert, majd ezt követően az olvashatósági teszttel gyakorlatban is megvizsgálnak holland nyelvü szövegeket (Van Laecke és Hadermann 2007: 52). Egy adott szöveg eredményét minden alkalommal egy 0 és 100 közötti tizedesjegyủ szám jelzi. Ezért úgy vélem, hogy valóban tipográfiai hiba lehet az általam fordított tanulmányban, így ezt a fordításban már javítottam. (Paulik Noémi)

A fordításnak önállóan kell megállnia a helyét a célnyelvi szövegek között, nem hivatkozhat a fordító az eredeti írásmü minőségi problémáira, ezért nem is szabad reprodukálnia a hibákat. Elírások és helyesírási hibák javítása nem is okoz különösebb gondot vagy etikai dilemmát, ténybeli tévedések esetén azonban már csupán alapos mérlegelés és utánajárás után módosíthat a szövegen a fordító - ahogyan a fenti kommentárban láthattuk -, és ilyenkor is mindig érdemes konzultálni a megbízóval, a lektorral, illetve az eredeti szerzővel, jelezve a felmerült problémát és a megoldásra tett javaslatot.

A legnagyobb kihívást a szakdolgozatokban szereplő fordítói kommentárok tanúsága szerint mégis a terminusok megfeleltetése jelentette. A fordítástudomány terminológiája egyelőre még nem tekinthető kiforrottnak, sem pedig rendszerezettnek, számos terminus esetében nem született még közmegegyezés (Klaudy 2020). Mi több, ahogyan a magyar fordítástudomány folyamatosan fejlődik, úgy keletkeznek újabb terminusok is. Különösen igaz ez a lektorálással foglalkozó szakirodalomra, ahol korántsem egységes a terminushasználat, sem nemzetközi, sem pedig hazai szinten (Horváth 2009; Robin 2018) A terminusok megfeleltetése során ezért a fordítóknak alaposan el kellett mélyülniük a fordítástudományi és a lektorálás témájában született szakirodalomban, kikeresve azokat a magyar nyelvü terminusokat, amelyek legjobban megállják a helyüket a célnyelvi szövegben.

A fordítás során a fordítóknak megkülönböztetett figyelmet kellett szentelniük az olyan terminusoknak, amelyek hasonlónak tünhetnek ugyan, de más-más jelentést hordoznak, és jelentésük definícióval meghatározható, ilyen például a forditási szöveg, a forditott szöveg és a fordítási nyelv. Gondos mérlegelést kívánt azoknak a terminusoknak a megfeleltetése is, ahol a szakirodalom egyelöre nem következetes, szinonimaként használ bizonyos terminusokat, jóllehet egyes szakmunkák már megkülönböztetik az érintett fogalmakat. Ide tartozik többek között a lektorálástudományi tanulmányokban gyakran előforduló szerkesztés és lektorálás (lásd Robin 2018). Az a körülmény is nehézséget okozhatott a fordítók számára, hogy bizonyos terminusok konnotációja idővel módosult, és immár nem használhatók eredeti jelentésükben. Ilyen például a nyersforditás, amelyet negatív konnotációja miatt nem alkalmazzuk az emberi fordítás jelölésére, inkább a gépi fordítás eredményére vonatkoztatjuk, míg az elöbbi esetben a szerkesztetlen forditás terminust használjuk. A terminusok megfeleltetésekor a fordítók az egyértelmüségre 
is törekedtek, hogy kerüljék a több jelentést is hordozó szakkifejezéseket, elkerülve az esetleges értelemzavart. Így járt el a fordító a verbális és az igei, a reverbalizáció és a visszaigésités terminuspár esetében, ahol a több jelentésü idegen szó helyett az egyértelmü magyar kifejezésre esett a választása.

Gyakran szembesültek a fordítók azzal a ténnyel is, hogy egy-egy forrásnyelvi terminus még nem rendelkezik magyar megfelelővel. Ilyenkor új terminusjelöltek alkotása válik szükségessé, tükörfordítással vagy új megnevezéssel, mégpedig a következö terminusalkotási elveket szem elött tartva: az új szakkifejezésnek szemantikailag transzparensnek (transparency), átláthatónak szükséges lennie vagyis a jelentése előre kikövetkeztethetö -; konzisztensnek és koherensnek (consistency és coherence) kell lennie a szakterület terminológiai rendszerével; ügyelni kell a terminus nyelvi gazdaságosságára (linguistic economy) és a létező jelentésmintázatoknak való megfelelésére (appropriateness), vagyis terminusalkotáskor törekedni kell az érthetőségre és egyértelmüségre; az újonnan alkotott kifejezésnek nyelvileg helyesnek (linguistic correctness), produktívnak és képezhetőnek (derivability és compoundability) szükséges lennie; továbbá törekedni kell az anyanyelvi kifejezések használatára az idegen nyelvű terminus kölcsönzése helyett (ISO 704: 2009). Hiányzó célnyelvi terminusok esetén a kölcsönzés mellett a körülírás stratégiáját is igyekeztek kerülni a fordítók, hiszen a tanulmányok fordításának és a kötetnek egyik kitüzött célja volt a magyar fordítástudományi terminológia gyarapítása és rendszerezése. Magyar terminusjelölt alkotását választották a fordítók az egyelőre csupán kölcsönzés útján ismert szakkifejezések esetében is. Ilyen döntés született a transediting megfeleltetésekor is, amely mostanáig csak eredeti formájában volt ismert a magyar szakirodalomban (Zachar 2019). A fordító döntéshozatal folyamatát az alábbi kommentár ismerteti:

Hosszú gondolkodás előzte meg a transediting terminus lefordítását. A terminusnak egyelöre még nincs magyar nyelvü megfelelöje, így már a cikk kiválasztásakor tudtam, hogy nekem kell megalkotnom. Eleinte a fordítás és a szerkesztés szó különböző kombinációival próbálkoztam (mint például a fordítás-szerkesztés, transzszerkesztés, szerkesztői fordítás), de mindegyiket nagyon komplikáltnak, eröltetettnek tartottam. Ezért kezdtem el az idegen kifejezéshez hasonló elnevezésen gondolkodni olyan terminusok nyomán, mint például a kreatív fordítást jelölő transzkreáció. Végül a témavezetőm segítségével a transzeditálás mellett döntöttünk azzal a kiegészítéssel, hogy a szerkesztőfordítás mint magyarázat segíthet a megértésben. - (Varga Dóra)

\section{5. Összefoglalás: a tanulmánykötet sikere}

A jelen beszámolóban bemutatott Lektorálástudomány - fordításban címü tanulmánykötet a fordítási és kiadási folyamat számos szereplöjének összefogása és támogatása eredményeként születhetett meg: a nemzetközi fordítástudomány lekto- 
rálással foglalkozó szaktekintélyei és a fordítások alapjául szolgáló tanulmányokat publikáló folyóiratok beleegyezésüket adták a kiválasztott cikkek magyar nyelven történő megjelentetéséhez; a szerzők közremúködésükkel segítették a fordítói munkát; a hallgatók az intézményes képzés során elsajátított tudásukról bizonyságot téve ültették át a tudományos müveket magyar nyelvre a szakmai, illetve a nyelvi lektor szerepében eljáró témavezetöik segítségével és irányításával; a szerkesztők egységes kötetbe rendezték a tanulmányokat; mindezekhez pedig az ELTE Bölcsészettudományi Kar Nyelvi Közvetítés Intézete Fordító- és Tolmácsképző Tanszéke biztosította az intézményes hátteret és támogatást. A könyv megszületése önmagában is jelentős siker, hiszen a projektet sikerült véghez vinni a cikkek kiválasztásától a szerzői jogok letárgyalásán és megszerzésén, majd a fordítási, lektorálási és szerkesztési folyamaton keresztül a tördelésig, végül pedig az internetes publikációig. Ám a tanulmánykötet több más szempontból is sikernek tekinthető.

Sikert könyvelhetnek el a hallgatók, akik közül sokak számára ez a feladat jelentette az első valódi fordítási megbízást és szakmai kihívást, így olyan tapasztalatra tehettek szert, amely későbbi pályafutásuk során is hasznosnak bizonyulhat, akár egyedül, akár csoportosan végezték a fordítási munkát, ahogyan az alábbiakban megfogalmazott vélemények is tükrözik:

„Örülök, hogy részt vehettem ebben a projektben. Hasznos tapasztalat volt, hozzájárult szakmai fejlődésemhez, és megerősítette a fordítói hivatás melletti elkötelezettségemet. Különleges meglepetés volt, hogy a forrásnyelvi szöveg szerzője, Mellinger professzor úr is értesült a fordításomról, és internetes oldalán örömmel közölte a hírt, hogy a cikkét magyarra fordították.” (Pete-Pikó Klára)

„Több szempontból is izgalmasnak találtam a projektet. Egyrészt mert ez volt az eddigi legnagyobb fordítási munkám, és bár eleinte ijesztőnek tünt a szöveg mennyisége, a téma iránti lelkesedésem és a publikálás gondolata mindig átlendített a nehézségeken.” (Böröndy Lilla)

A projektben elsőévesként részt vevő hallgatók további szakmai kompetenciák és kihívások terén is tapasztalatot szerezhettek, meg kellett birkózniuk a csapatmunka nehézségeivel, de élvezhették annak elönyeit is, ugyanakkor a lektorálási feladatba is belekóstolhattak:

„A tanulmánykötethez hozzájáruló fordítók közül talán a mi négyesünk volt az egyedüli, amely elsőévesként próbálhatta ki magát. Szintén egyedüliként, négyfös fordítócsapatként dolgoztunk, ez részben könnyebbé, részben nehezebbé tette a fordítói munkát. Csapatként mindenkinek meg kellett tanulnia meghallgatni a másikat, és egységként együttmüködni. A csapatmunka rávilágított, hogy újdonságokat tanulhatunk egymástól, kiegészíthetjük és szakmailag elörelendíthetjük egymást. A közös munka során egymás lektoraiként 
is részt vettünk a projektben, így érdekes volt rögtön azokat a kompetenciákat is használni, amelyekről a fordítandó szövegünkben szó esett." (Sulyok Kamilla, Babarczy Katalin, Pál Zsófia, Vatai Barbara)

Ahogyan a fenti véleményböl kitünik, a projektben részt vevő hallgatók nem csupán gyakorlati tapasztalatra tehettek szert a tanulmányok magyar nyelvre történő átültetése során. A fordítandó szövegek témája lehetőséget nyújtott számukra a fordítástudományban és azon belül is a lektorálással foglalkozó szakirodalomban való elmélyülésre, így saját stratégiáikra, eljárásaikra is reflektálhattak munka közben, elösegítve a tudatosabb fordítást. Ilyen módon a projekt eredményeként gyakorlati és elméleti tudással is gazdagodhattak a fordításról és a lektorálásról egyaránt, ahogyan az alábbi fordítói vélemény is megfogalmazza:

„Christina Schäffner cikkét fordítani és a transzeditálás fogalmát megismerni rendkívül gondolatébresztő élmény volt számomra. Eleinte nem tulajdonítottam nagy jelentőséget a transzeditálás fogalmának, arra gondoltam, a fordítás az csak fordítás, én magam nem végzek semmilyen szerkesztői tevékenységet fordítás közben. Ám amint egyre jobban beleástam magam a témába, világossá vált számomra, hogy az igényes fordítás nem csupán a szavak lefordítása, hanem rengeteg egyéb - szerkesztői - folyamatot is magában foglal. A fordítás során többször is transzeditálást hajtottam végre, ami frappáns csavart jelentett számomra. A cikk maga, illetve az egész projekt - a fordítási és a lektorálási folyamatot is beleértve - remek élmény volt, és büszkeséggel tölt el, hogy a részese lehettem." (Varga Dóra)

A tanulmánykötet megjelenését sikerként könyvelhetik el maguk a cikkek szerzői is, akik beleegyezésüket adták a munkájuk magyar nyelvre való fordításához, hiszen újabb publikációt könyvelhetnek el a munkásságukban, és a fordítás eredményeként olyan kutatókhoz is eljuthat a tanulmányuk, akik megfelelő nyelvtudás híján nem ismerhették volna meg a gondolataikat, így szélesebb tudományos körben is ismertté válhat a munkájuk. A projekt továbbá egyedülálló lehetőséget biztosított a szerzők számára, hogy a világ különböző országaiban lektorálással foglalkozó, sokszor egymásra is hivatkozó - gyakran idézett és egyelőre még kevésbé ismert - fordításkutatók egy tematikus tanulmánykötetben „találkozhassanak” egymással. Bizonyára külön „élményt” jelent a forditáskutatók számára, hogy a munkájuk fordításban jelenik meg - különösen, mivel tudományterületünkön inkább az önfordítás jellemző (Pusztai-Varga 2018). Ezen gondolataikat a szerzők visszajelzéseikben is kifejezték, ahogy az alábbiakban olvasható:

„Many thanks, I'm honoured to see my work has been translated and I remember from the correspondence with my translator that she has worked very hard and with attention to detail! I'm grateful to be published in this volume and great company." (Mario Bisiada) 
„I too wish to express my congratulations and thanks for this excellent work. The students in particular can be proud of this achievement. I too am honoured that my paper is included." (Christina Schäeffner)

„I am writing to say many thanks to you for your Hungarian translation of my article „Re-thinking translation quality: Revision in the digital age”. It is the first time I have been translated, and it is exciting and humbling to think my work was of interest to you to merit translation. I am honored to have my work appear alongside everyone else in the volume. I hope colleagues find it of interest in Hungary!" (Chris Mellinger)

A tanulmánykötet remélhetőleg még egy további szempontból is sikernek bizonyul: a tudományos értékét tekintve. Tudományos szempontból egyrészt máris sikerként könyvelhetö el, hiszen a kötetben szereplő magyar nyelvü szövegek a tudományos szakfordítást képviselik. A tudományfordítás jelentősége kapcsán pedig Károly (2019: 5) a következőképpen fogalmaz: „a tudományos szakfordítás nem csak filológiai kérdés: meghatározó tényező a tudomány és az emberiség tudományos gondolkodásának alakulásában, fejlődésében”. A tudományos cikkek fordítóinak tehát tudományformáló szerep is jut, nem egyszerüen szövegeket ültetnek át egyik nyelvről a másikra: megteremtik a kapcsolatot a nemzetközi szakirodalom, vagyis az egyazon tudományterület különböző nyelvi és kulturális háttérből származó képviselői között, segíthetik a célnyelven folyó szakszerü, következetes tudományos diskurzust, valamint hozzájárulhatnak egy adott tudományterület egységes és szakszerű terminológiájának kialakításához.

Különösen igaz lehet ez az olyan felemelkedő diszciplínák esetében, mint amilyen a fordítástudomány, amelynek önállósága időnként még mindig vitatott kérdés (Klaudy 2020), illetve ugyanez elmondható a berkein belül elinduló, fordítások lektorálásával foglalkozó kutatási irányzattal kapcsolatban is. A jelen beszámoló tárgyát képezö tanulmánykötet címe, Lektorálástudomány - fordításban, sokak számára talán túlságosan is ambiciózusnak tünhet, hiszen egyelöre a fordítástudomány helyzete sem szilárdult meg a tudományos köztudatban. Mindazonáltal a lektorálástudomány létjogosultága felmerült a magyar szakirodalomban is (Horváth 2009; Robin 2015, 2018). A kötetbe válogatott tanulmányok pedig arról tanúskodnak, hogy a lektorálásról szóló tudományos irányzat képes meghatározni és leírni a kutatása tárgyát, saját terminusokkal és kutatási módszerekkel rendelkezik, empirikus eredményeivel törekszik az általánosíthatóságra és a lektorálás jellegzetes jelenségeinek előrejelzésére, valamint igyekszik a területen tevékenykedő szakemberek közötti konszenzusra (lásd Klaudy 2020; egy tudomány érettségérôl). Ilyen módon, ha önálló tudományként egyelőre nem is, a lektorálástudomány aldiszciplínaként bizonyára megállhatja a helyét. A kötet szerkesztői és fordítói mindenesetre bíznak benne, hogy a lefordított tanulmányok hozzájárulhatnak a magyar nyelvterületen folyó, lektorálással kapcsolatos kutatások folytatásához és elméleti hátterének megalapozásához. 


\section{A kötetben (Robin és Zachar 2020) megjelent tanulmányok:}

Christina Schäffner: A transzeditálás újragondolása. Fordító: Varga Dóra.

Julie McDonough Dolmaya: Laptörténet: forditási trendek a Wikipédián. Fordító: Sztanó Kata Kincső.

Mario Bisiada: Nominalizációk lektorálása angol-német forditásokban: mikor avatkozik be a lektor? Fordító: Miller Barbara.

Christopher D. Mellinger: A fordítások minöségének újragondolása: lektorálás a digitális korban. Fordító: Pete-Pikó Klára.

Isabelle S. Robert, Aline Remael, Jim J. J. Ureel: Úton a lektorálási kompetencia modellezése felé. Fordító: Fesztóryné Deák Diána.

Alexander Künzli: A fordítások lektorálása: fogalommeghatározások, a kutatások jelenlegi állása, lehetséges kutatási területek. Fordító: Turi Bernadett és Kornokovits Bianka.

Isabelle S. Robert: Egynyelvü átolvasás: gyors, funkcionális, de nem megbizható eljárás a forditás lektorálására. Fordító: Paulik Noémi.

Giovanna Scocchera: Olvasási technikák a lektorálásban: a lektorálási folyamat fordítói és lektori megközelítésének aspektusai. Fordító: Dobróka Anett.

Louise Brunette és Chantal Gagnon: A lektorálás oktatása a wikik korában: ott találunk rá a technológiára, ahol már nem is várnánk. Fordító: Böröndy Lilla.

Isabelle S. Robert: A lektorálás kutatása: bibliometrikus ismertetés, kutatási kérdések és módszerek. Fordító: Babarczy Katalin, Pál Zsófia, Sulyok Kamilla és Vatai Barbara.

Britta Nord: A forditások lektorálása-mühelyjelentés. Fordító: Galac Ádám.

Kristine Bundgaard, Tina Paulsen Christensen és Anne Schjoldager: A forditó és a számitógép interakciója: egy számítógéppel támogatott fordítási munkafolyamat megfigyelése. Fordító: Nyírfás Ágnes.

\section{Irodalom}

Fata I. 2012. Német középfokú oktatási intézmények Magyar nyelvű ekvivalenseinek korpuszalapú vizsgálata. In: Dróth J. (szerk.) Szaknyelv és szakforditás. Gödöllő: SZIE. $32-45$.

Ferreira, A., Wayne Schwieter, J., Gottardo, A., Jones, J. 2016. Cognitive effort in direct and inverse translation performance: insight from eye-tracking technology. Cadernos de Tradução Vol. 36. No. 3. 60-80. https://doi.org/10.5007/2175-7968.2016v36n3p60.

Horváth P. I. 2009. A lektori kompetencia. Doktori értekezés. Kézirat. Budapest.

Halliday, M. A. K. 1985. (2004) An Introduction to Functional Grammar. 3rd edition. London: Arnold.

Károly K. 2019. Tudományfordításról fordítástudományi megközelítésből. Forditástudomány 21. évf. 2. szám. 5-16. https://doi.org/10.35924/fordtud.21.2.1

Klaudy K. 1997. Forditás és aktuális tagolás. Budapest: Akadémiai Kiadó.

Klaudy K. 2014. A fordítástudomány neve, természete és terminológiája. In: Navracsics J. (szerk.) Transzdiszciplináris üdvözletek Lengyel Zsolt számára. Budapest, Veszprém: Gondolat Kiadó, Pannon Egyetem MFTK. 9-19.

Klaudy K. 2020. Közös nyelvet beszélünk? Ami a 123 fordítástudományi terminusból kimaradt. In: Fóris Á., Bölcskei A. (föszerk.) Nyelv, kultúra, identitás. Alkalmazott 
nyelvészeti kutatások a 21. századi információs térben. XXVII. MANYE Kongreszszus. KGRE Budapest, 2019. április 15-16. I. rész: Fóris Á., Pintér T., Szoták Sz., Tamás D. M. (szerk.) Terminológia, lexikográfia, fordítás. Budapest: Akadémiai Kiadó (MERSZ).

Malaczkov Sz. 2020. Feliratok didaktikai célú lektorálása. In: Fóris Á., Bölcskei A., M. Pintér T., Szoták Sz., Tamás D. M. (szerk.) Nyelv, kultúra, identitás. Alkalmazott nyelvészeti kutatások a 21. századi információs térben: XXVII. MANYE Kongreszszus. KGRE Budapest, 2019. április 15-16. I. rész: Fóris Á., Pintér T., Szoták Sz., Tamás D. M. (szerk.) I. Terminológia, lexikográfia, fordítás. Budapest: Akadémiai Kiadó (MERSZ).

Mohácsi-Goove A. 2014. A minőség fogalma a fordítástudományban és a lektorálás mint minőségbiztosítási garancia. Doktori disszertáció. Budapest: ELTE.

Pusztai-Varga I. 2018. Többszörös határátlépés: tudományos szövegek önfordítása. In: Robin E., Zachar V. (szerk.) Forditástudomány ma és holnap. Budapest: L'Harmattan. $142-156$.

Robert, I. S. 2018. La recherche en révision : portrait bibliométrique, questions de recherche et méthodologies. Paralleles Vol. 30. No. 2. 129-152. https://doi.org/10.17462/ para.2018.02.07

Robin E. 2015. Fordítási univerzálék a lektorált fordításokban. Budapest. Doktori értekezés.

Robin E. 2018. Beszámoló egy hallgatói projektről: Forditástudomány-fordításban. Fordítástudomány 20. évf. 2. szám. 133-138.

Robin E. 2019. Munkaharmónia a fordításszolgáltatásban, avagy a lektorálás etikai kérdései. In: Szoták Sz. (szerk.) Diszciplínák találkozása: nyelvi közvetítés a XXI. században. Budapest: OFFI. 120-134.

Robin E., Varga D. Á. (szerk.) 2018. Fordítástudomány - fordításban. Budapest: ELTE BTK Fordító- és Tolmácsképző Tanszék.

Robin E., Zachar V. (szerk.) 2020. Lektorálástudomány - fordításban. Budapest: ELTE BTK Nyelvi Közvetítés Intézete, Fordító- és Tolmácsképző Tanszék.

Van Laecke, G., Hadermann, P. 2007. Le Traité constitutionnel européen. Enquête sur la lisibilité du texte et le degré de compréhension des citoyens. Gent: Universiteit Gent.

Wakabayashi, J. 2009. An etymological exploration of 'translation' in Japan. In: Wakabayashi, J., Kothari, R. (eds) Decentering Translation Studies: India and beyond. Amsterdam/Philadelphia: John Benjamins Publishing Company. 175-194. https://doi. org/10.1075/btl.86.15wak

Zachar V. 2019. Müveletek a sajtófordításban. In: Nyomárkay I., Nagy S. I. (szerk.) A fordítás elméleti és gyakorlati kérdései. Budapest: Modern Filológiai Társaság. 325-340. 